\title{
Settlement Prediction of Soil at Closed Dumping area using Power Creep Function
}

\author{
Nur Irfah Mohd Pauzi ${ }^{1, a^{*}}$, Husaini Omar ${ }^{2, b}$ Halina Misran ${ }^{3, c}$ \\ Siti Zubaidah Othman ${ }^{3, c}$ and Abreeza Manap ${ }^{3, c}$ \\ ${ }^{1}$ Civil Engineering Department, College of Engineering, Universiti Tenaga Nasional, Jalan IKRAM- \\ UNITEN, 43009 Kajang, Selangor, Malaysia \\ ${ }^{2}$ MTDRC, Level 9, Engineering Tower Block, Faculty of Engineering, Universiti Putra Malaysia, \\ 43300 UPM Serdang, Selangor, Malaysia \\ ${ }^{3}$ Nanoarchitectonic Laboratory, College of Engineering, Universiti Tenaga Nasional, Jalan IKRAM- \\ UNITEN, 43000 Kajang, Selangor, Malaysia \\ a*irfah@uniten.edu.my, 'busaini@upm.edu.my, chalina@uniten.edu.my
}

\section{Keywords: Soil Settlement Prediction, Power Creep Function, Geotechnical Parameters of Waste Soil}

\begin{abstract}
In Malaysia, total dumping sites are 73 sites, controlled dumping sites are 71 sites and sanitary landfill are 11 sites. These disposal sites will increase over time because population in Malaysia has been increased at a rate of 2.4\% per annum or about 600,000 per annum since 1994 . The increase in population would increase the amount of waste generated. Thus, it will increase the number of dumping sites. The dumping area which has a full capacity of waste will eventually closed. These closed dumping area which are to be developed for new development are prone to settlement. The settlement at dumping area are to be predicted and simulated using Power Creep Function. The heterogeneous content of waste soil from dumping area are complicated to characterize and classified. The content of waste dumped at the dumping area is important to analyse because the degradation process changes with time. The degradation process are called power creep function. Power Creep Function (PCF) is time dependent deformation which is under constant stress. The two constant variables which are $\mathrm{M}^{\prime}$ and $\mathrm{N}^{\prime}$. $\mathrm{M}^{\prime}$ is the compressibility constant and $\mathrm{N}^{\prime}$ is rate of compression varies with age placement condition. The input parameters for PCF are $\mathrm{H}_{0}, \Delta \sigma, \mathrm{t}, \mathrm{Tr}, \mathrm{M}^{\prime}$ and $\mathrm{N}^{\prime}$. These parameters are simulated based on two cases whereby, case 1 where $\mathrm{M}^{\prime}$ and $\mathrm{N}^{\prime}$ are kept constant and time (t) increases from 25 days to 75 days. $\mathrm{Tr}$ is kept constant at 1 day. Case 2 is where $M^{\prime}, N^{\prime}$ and $\operatorname{Tr}$ are kept constant and time (t) increases from 240 days to 730 days. The settlement prediction at the dumping area for Case 1 is 0.024 meters to 0.042 meters and for Case 2 the settlement is in the range of 0.074 meters to 0.130 meters. The prediction of total settlement for dumping area would be used to determine the depth of foundation for the new development at the dumping area.
\end{abstract}

\section{Introduction}

The settlement behaviors of waste at the abandoned dumping sites are important for the development of the area. The abandoned dumping area, if not used for new development will be wasted because the area could be developed for new development. The major problem in reusing the dumping area would be the settlement of the area. Therefore, this paper is attempted to predict the settlement of the open dumping area using power creep function. The power creep function is coupled with the statistical model to predict the settlement of the dumping area.

\section{Settlement Prediction Model}

There are many mathematical models that can predict settlement of waste soil. The mathematical models are such as soil mechanics based model [1], Bjarngard and Edgers model [2] hyperbolic 
function [3], power creep function [4] and rheological model [5]. The settlement predictions of waste for this research are focusing on power creep function model. Power creep function model is the time dependent deformation which is under constant stress. The rates of compression are very slow and it varies with the age of placement of waste condition.

The dumping area selected for this study is near Kuala Lumpur area. The dumping site is an open dumping area which the waste are dump without proper waste system collection. The dumping area is not covered with soil after the waste has been dumped. The total height of the waste at the time is approximately 30 meters height. The age of placement is 2 years. There are two cases of settlement such as primary settlement and secondary settlement. Primary settlement is where the volume change occurring up to the full dissipation of excess pore pressures, while secondary settlement are due to creep which the rearrangement of internal particle mechanism which is similar to compaction but occurring slowly. The settlement prediction were analyze for two cases where the time is from 25 days to 75 days for primary settlement and 240 days to 730 days for secondary settlement. This research attempted to predict settlement after two years the waste has been dumped at open dumping area in Kuala Lumpur dumping area. The combinations of power creep function and Monte Carlo simulation are presented in this research.

\section{Power Creep Function Model}

The power creep function model is a simple relation for time-dependent deformation under constant stress and expressed as the following Eq. 1 by [4].

$$
\Delta \mathrm{H}=\mathrm{H}_{0} \Delta \sigma \mathrm{M}^{\prime}\left(\mathrm{t} / \mathrm{t}_{\mathrm{r}}\right)^{\mathrm{N}^{\prime}}
$$

Where $\Delta \mathrm{H}$ is the settlement, $\mathrm{H}_{0}$ is initial height of waste, $\Delta \sigma$ is compressive stress depending upon waste height, density and external loading, $M^{\prime}$ 'is reference compressibility which is in the range of $1.6 \times 10^{-5}$ to $5.8 \times 10^{-5} / \mathrm{kPa}, \mathrm{N}^{\prime}$ is the rate of compression which is in the range of 0.5 to $0.67, \mathrm{t}$ is the time since load application and $\mathrm{t}_{\mathrm{r}}$ is the reference time which is typically introduced to make time dimensionless and usually taken as 1 day [6]. The parameter $M^{\prime}$ is site specific and $N^{\prime}$ is the rate of compression which varies with respect to age and placement conditions of the waste. However the variability of $N^{\prime}$ is less than that of $\mathrm{M}^{\prime}$ [4]. The power creep function model is used in the settlement prediction because the soil which contains waste takes slow time for the digestion of microbe. The time are the main parameters in this settlement prediction model and this method is the most reliable method as compared with other settlement model such as soil mechanics based model, Bjarngard and Edgers model, hyperbolic function and rheological model.

\section{Materials and Method}

The research was conducted at the open dumping area near Sri Hartamas Kuala Lumpur. The total numbers of samples collected are approximately about 10 samples. The samples collected using hand auger method following the ASTM D6907 [7] guidelines for sampling of soils. The samples collected are after the load application. Then the dumping area has been stop from taking anymore waste. Thus, the testing of the geotechnical properties were done after the dumping area has been closed.

The samples collected were tested on its geotechnical properties based on the ASTM guidelines. The sieve analysis of the soil are conducted based on ASTM D422 [7], specific gravity test based on ASTM D854 [7], consolidation test are based on ASTM D2435 [7], direst shear test are based on ASTM D3080 [7], compaction test are based on ASTM D698 [7], and finally the triaxial test are based on ASTM D2850 [7]. After the geotechnical properties of the soil have been established, the power creep function model is used for settlement prediction. 
As mention in the literature review, the power creep function model is used to predict the settlement from 25 days to 730 days. There are two cases in this research. For case 1, the time of settlement is increased from 25 days to 75 days. Furthermore, for Case 2, the time of settlement is increased from 240 days to 730 days. The power creep function model is used to predict the total settlement after the open dumping area has been closed. The new development of the area will take place after the settlement has been stabilized.

Geotechnical Parameters of Soil at Closed Dumping Area The soil samples were collected at the dumping area. The laboratory testing such as sieve analysis test, direct shear test, specific gravity, one-dimensional consolidation test, compaction test and triaxial test were conducted to determine the basic geotechnical properties of the waste soil. The details of the geotechnical properties of waste soil are shown in Table 1. The soil samples consist of concrete debris waste approximately $30 \%$ to $35 \%$.

Table 1 Geotechnical properties of Waste Soil [8]

\begin{tabular}{lc}
\hline \multicolumn{1}{c}{ Geotechnical Parameters } & Range Values \\
\hline PSD (\%) Concrete Debris & $30-35$ \\
$\mathrm{G}_{\mathrm{s}}$ & $2-2.16$ \\
Shear Strength & \\
$\quad$ (a) Friction Angle $\left({ }^{\circ}\right)$ & $11-38$ \\
(b) Cohesion (kPa) & $0-5$ \\
Displacement (mm) & $0.5-3.5$ \\
Settlement Rate (mm/min) & $0.018-0.035$ \\
Dry Density (kg/m $\left.{ }^{3}\right)$ & $1489-1600$ \\
Optimum Moisture Content (\%) & $27-30$ \\
Triaxial Strength & $0-10$ \\
(a) Friction Angle $\left({ }^{\circ}\right)$ & $3-10$ \\
(b) Cohesion (kPa) & $89-155$ \\
(c) Major Principal Stress (kPa) & $60-100$ \\
(d) Minor Principal Stress (kPa) & \\
\hline
\end{tabular}

Statistical Parameters for Power Creep Function The power creep function parameters used for simulation using statistical modeling are tabulated in Table 2 . The number of simulation is $\mathrm{n}=16$. The initial height of waste is 30 meters. The $\mathrm{M}^{\prime}=0.00016$ which is constant and $\mathrm{N}^{\prime}=0.5$ which is constant. The $\operatorname{tr}$ is the time reference which is 1 day. Furthermore, $t$ is the time for the settlement which for this case is increased from 25 days to 75 days. The total settlement $(\Delta \mathrm{H})$ from statistical modeling for case 1 are in the range of 0.024 meters to 0.042 meters. Fig. 1 shows the settlement versus the number of iteration for Case 1 . 
Table 2 Power creep function model parameters for statistical modeling (Case 1)

\begin{tabular}{llllcccc}
\hline $\mathrm{N}$ & $\begin{array}{l}\mathrm{H}_{0} \\
(\mathrm{~m})\end{array}$ & $\begin{array}{l}\Delta \sigma \\
(\mathrm{kPa})\end{array}$ & $\begin{array}{l}\mathrm{M}^{\prime} \\
(\mathrm{kPa})\end{array}$ & $\mathrm{N}^{\prime}$ & $\mathrm{t}^{(\text {day })}$ & $\begin{array}{l}\mathrm{Tr} \\
(\text { day })\end{array}$ & $\begin{array}{l}\Delta \mathrm{H} \\
(\mathrm{m})\end{array}$ \\
\hline 1 & 30 & 10 & 0.000016 & 0.5 & 25 & 1 & 0.024 \\
2 & 30 & 10 & 0.000016 & 0.5 & 26 & 1 & 0.024 \\
3 & 30 & 10 & 0.000016 & 0.5 & 27 & 1 & 0.025 \\
4 & 30 & 10 & 0.000016 & 0.5 & 28 & 1 & 0.025 \\
5 & 30 & 10 & 0.000016 & 0.5 & 29 & 1 & 0.026 \\
6 & 30 & 10 & 0.000016 & 0.5 & 30 & 1 & 0.026 \\
7 & 30 & 10 & 0.000016 & 0.5 & 35 & 1 & 0.028 \\
8 & 30 & 10 & 0.000016 & 0.5 & 37 & 1 & 0.029 \\
9 & 30 & 10 & 0.000016 & 0.5 & 40 & 1 & 0.030 \\
10 & 30 & 10 & 0.000016 & 0.5 & 45 & 1 & 0.032 \\
11 & 30 & 10 & 0.000016 & 0.5 & 49 & 1 & 0.034 \\
12 & 30 & 10 & 0.000016 & 0.5 & 54 & 1 & 0.035 \\
13 & 30 & 10 & 0.000016 & 0.5 & 60 & 1 & 0.037 \\
14 & 30 & 10 & 0.000016 & 0.5 & 63 & 1 & 0.038 \\
15 & 30 & 10 & 0.000016 & 0.5 & 67 & 1 & 0.039 \\
16 & 30 & 10 & 0.000016 & 0.5 & 75 & 1 & 0.042 \\
\hline
\end{tabular}

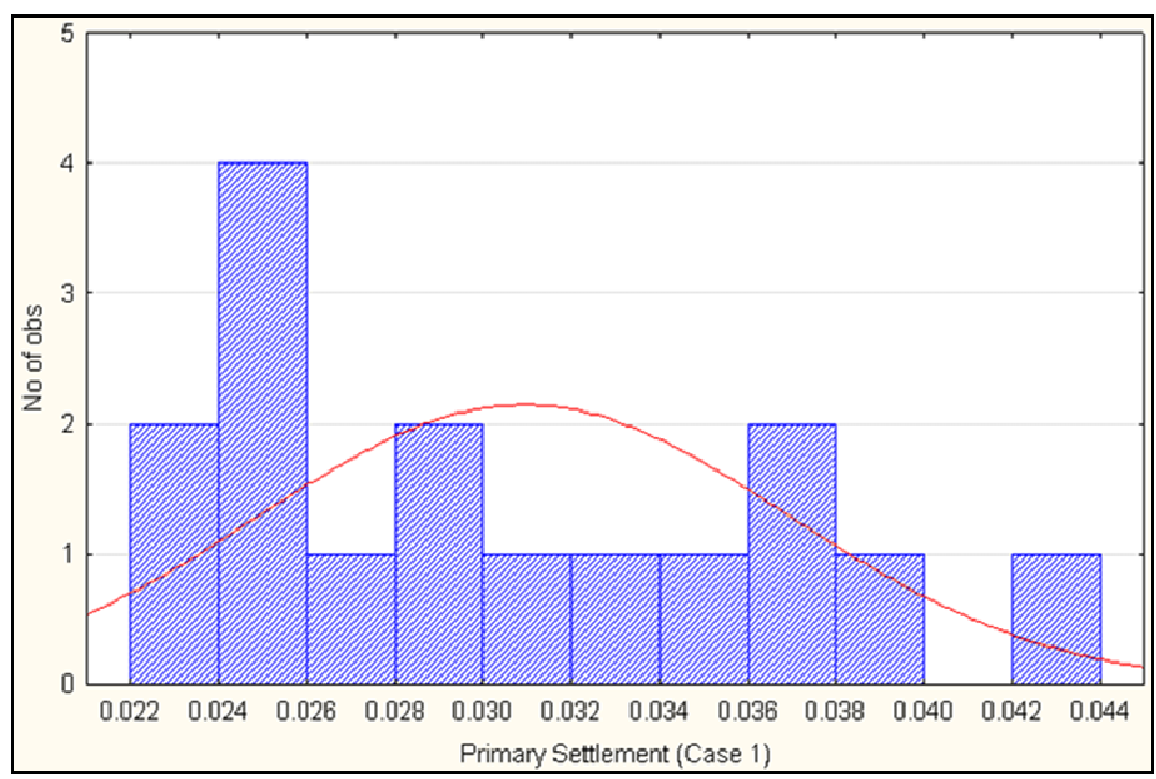

Fig. 1 Settlement vs. Number of iteration (Case 1)

As for case 2, the power creep function parameters used for simulation using statistical modeling are tabulated in Table 3. The number of simulation is $n=16$. The initial height of waste is 30 meters. The $\mathrm{M}^{\prime}=0.00016$ which is constant and $\mathrm{N}^{\prime}=0.5$ which is constant. The tr is the time reference which is 1 day. Furthermore, $t$ is the time for the settlement which for this case is increased from 240 days to 730 days. Figure 2 show the settlement simulation by statistical modeling. The total settlement $(\Delta \mathrm{H})$ for Case 2 is in the range of 0.074 meters to 0.130 meters. Fig. 2 shows the settlement versus the number of iteration for Case 2. 
Table 3 Power creep function model parameters for statistical modeling (Case 2)

\begin{tabular}{llllllll}
\hline $\mathrm{N}$ & $\begin{array}{l}\mathrm{H}_{0} \\
(\mathrm{~m})\end{array}$ & $\begin{array}{l}\Delta \sigma \\
(\mathrm{kPa})\end{array}$ & $\begin{array}{l}\mathrm{M}^{\prime} \\
(/ \mathrm{kPa})\end{array}$ & $\mathrm{N}^{\prime}$ & $\mathrm{t}_{\text {(day) }}$ & $\begin{array}{l}\mathrm{Tr} \\
(\mathrm{day})\end{array}$ & $\begin{array}{l}\Delta \mathrm{H} \\
(\mathrm{m})\end{array}$ \\
\hline 1 & 30 & 10 & 0.000016 & 0.5 & 240 & 1 & 0.074 \\
2 & 30 & 10 & 0.000016 & 0.5 & 260 & 1 & 0.077 \\
3 & 30 & 10 & 0.000016 & 0.5 & 300 & 1 & 0.083 \\
4 & 30 & 10 & 0.000016 & 0.5 & 340 & 1 & 0.089 \\
5 & 30 & 10 & 0.000016 & 0.5 & 360 & 1 & 0.091 \\
6 & 30 & 10 & 0.000016 & 0.5 & 400 & 1 & 0.096 \\
7 & 30 & 10 & 0.000016 & 0.5 & 450 & 1 & 0.102 \\
8 & 30 & 10 & 0.000016 & 0.5 & 500 & 1 & 0.107 \\
9 & 30 & 10 & 0.000016 & 0.5 & 550 & 1 & 0.113 \\
10 & 30 & 10 & 0.000016 & 0.5 & 570 & 1 & 0.115 \\
11 & 30 & 10 & 0.000016 & 0.5 & 590 & 1 & 0.117 \\
12 & 30 & 10 & 0.000016 & 0.5 & 600 & 1 & 0.118 \\
13 & 30 & 10 & 0.000016 & 0.5 & 625 & 1 & 0.120 \\
14 & 30 & 10 & 0.000016 & 0.5 & 650 & 1 & 0.122 \\
15 & 30 & 10 & 0.000016 & 0.5 & 700 & 1 & 0.127 \\
16 & 30 & 10 & 0.000016 & 0.5 & 730 & 1 & 0.130 \\
\hline
\end{tabular}

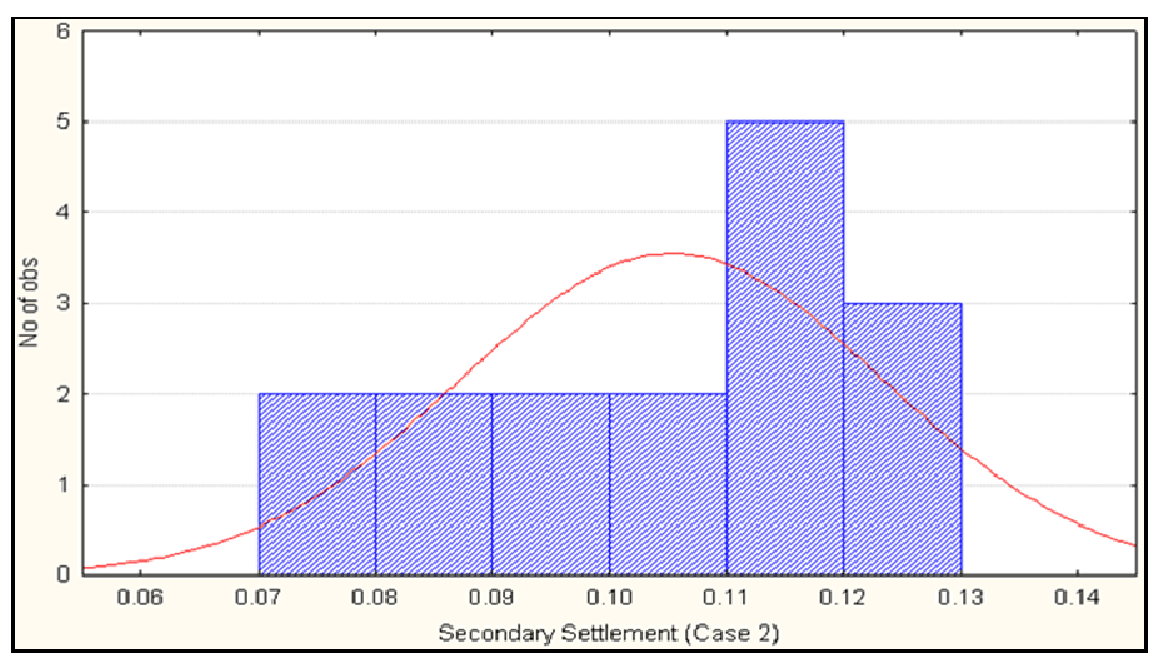

Figure 2: Settlement vs. Number of iteration (Case 2)

\section{Discussion}

Settlement at the open dumping area could be predicted using power creep function method. The power creep function takes into account the time since load application, the age of the landfill, the initial height of the waste, compressibility rate and rate of compression. The simulation based on the statistical modeling using $\mathrm{n}=16$ number of iterations show that the settlement are in the range of 0.024 meters to 0.042 meters for case 1 and in the range of 0.074 meters to 0.130 meters for case 2 . It can be concluded that the highest total settlement is 0.13 meters based on statistical modeling. The settlement prediction would help the geotechnical engineer in designing the depth of foundation which must be more than 0.13 meters as predicted by power creep function. The settlement prediction was done for 2 years duration which is 730 days. This result can be compared with other model as shown in Table 4 for its reliability and validity. It can be concluded that the lowest settlement is 0.130 meters from the power creep function model. The highest total settlement is Bjarngard and Edgers model which is 6.131 meters. Due to the small value of compressibility, the power creep function are the lowest as compared to other models. This depend on the creep function 
of the organic waste that consist in the soil. While other model does not takes into account of the compression ratio except for Bjarngard and Edgers model.

Table 4 Soil Engineering Parameters from other Settlement Model

\begin{tabular}{|c|c|c|c|c|}
\hline $\begin{array}{l}\text { Settlement } \\
\text { Model }\end{array}$ & $\begin{array}{l}\text { Parameters and } \\
\text { Values }\end{array}$ & & $\begin{array}{c}\text { Basis for } \\
\text { parameter } \\
\text { values } \\
\end{array}$ & $\begin{array}{c}\text { Total } \\
\text { settlement }\end{array}$ \\
\hline $\begin{array}{l}\text { Soil mechanics } \\
\text { based model }\end{array}$ & Time (days) & $\begin{array}{c}\text { Compression ratio } \\
\left(\mathrm{C}^{*}\right)\end{array}$ & & (m) \\
\hline (Sowers, 1973) & $\begin{array}{c}t<2 \times 10^{2} \\
t=2 \times 10^{2}-2 \times 10^{3} \\
t=2 \times 10^{3}-2 \times 10^{4} \\
t=2 \times 10^{2}-2 \times 10^{3}\end{array}$ & $\begin{array}{l}0.106 \\
0.184 \\
0.174 \\
0.163\end{array}$ & [9] & 1.139 \\
\hline & $\mathrm{C}_{\alpha}=0.035$ & $\mathrm{t}_{1}=1-25$ days & [6] & \\
\hline Bjarngard and & $\mathrm{C}_{\alpha 1}=0.035$ & & & \\
\hline $\begin{array}{l}\text { Edgers model } \\
\text { (Bjangard and } \\
\text { Edgers, 1990) }\end{array}$ & $\begin{array}{c}\mathrm{C}_{\alpha 2}=0.215 \\
\mathrm{t}_{1}=1-25 \text { days } \\
\mathrm{t}_{2}=200 \text { days } \\
\mathrm{C}_{\mathrm{c}} *=0.106\end{array}$ & & [2] & 6.131 \\
\hline $\begin{array}{l}\text { Power creep } \\
\text { function } \\
\text { (Edil et al. } \\
\text { 1990) }\end{array}$ & $\begin{array}{c}\mathrm{M}^{\prime}=1.7 \times 10^{-5} / \mathrm{kPa} \\
\mathrm{N}^{\prime}=0.50 \\
\operatorname{Tr}=1 \text { day }\end{array}$ & & [6] & 0.130 \\
\hline $\begin{array}{l}\text { Hyperbolic } \\
\text { function } \\
\text { (Ling et al., } \\
1998 \text { ) }\end{array}$ & $\begin{array}{c}\rho_{\mathrm{o}}=0.001 \mathrm{~m} / \mathrm{day} \\
\mathrm{S}_{\mathrm{ult}}=1.140 \mathrm{~m} \\
\mathrm{tc}^{*}=1 \mathrm{month}\end{array}$ & & $\begin{array}{c}{[3]} \\
{[10]}\end{array}$ & 0.198 \\
\hline $\begin{array}{l}\text { Rheological } \\
\text { Model } \\
\text { (Gibson and } \\
\text { Lo, 1961) }\end{array}$ & $\begin{array}{c}\mathrm{a}=0.0001 \\
\mathrm{~b}^{\prime}=0.00305 \\
\lambda / \mathrm{b}^{\prime}=0.0009\end{array}$ & & [6] & 0.882 \\
\hline
\end{tabular}

\section{Conclusion}

The settlement of the waste soil at open dumping area is very difficult to predict due to the heterogeneous content of the waste. Although there are many mathematical models to predict settlement, the use of power creep function model is helpful in calculating the settlement prediction for settlement containing waste in dumping area. Power creep function which consider the time since the load application, the age of landfill, the compressibility of the soil and the rate of compression make the settlement calculation more accurate. The settlement prediction at the dumping area for Case 1 is 0.024 meters to 0.042 meters and for Case 2 the settlement is in the range of 0.074 meters to 0.130 meters. The power creep function model is reliable in predicting the settlement as compared with other model because power creep function consider the biodegradation process which requires time for the microbe to digest the organic waste. Thus the total settlement for the waste soil is the lowest in power creep function as compared to the other model. The prediction of total settlement for dumping area would be used to determine the depth of foundation for the new development at the dumping area. 


\section{Acknowledgement}

The author wishes to acknowledge the Ministry of Education of Malaysia for supporting this research under grant No. 20140110 FRGS. Thank you to Universiti Tenaga Nasional (UNITEN) for the laboratory facility and library.

\section{References}

[1]Sowers G.F: Settlement of waste disposal fills, Proc $8^{\text {th }}$ Int. Conf. on Soil Mechanics and Foundation Engineering, Moscow, Vol. 1, 2 (2) (1973) p. 207-210

[2]A. Bjarngard and L. Edgers: Settlement of municipal solid waste landfills, Proc. $13^{\text {th }}$ Annual Madison Waste Conf., University of Wisconsin, Madison, Wis (1990) p. 192-205

[3] H.I. Ling, D. Leschchnsky, I. Mohri and T. Kawabata: Estimation of municipal solid waste landfill settlement, Journal Geotech. Geoenvironment. Eng., 124 (1), (1998) p. 21-28

[4] T.B. Edil, V.J. Ranguette and W.W. Wuellner: Settlement of municipal refuse, Geotechnics of wastefill: Theory and Practice, STP 1070, A Landva and G.D. Knowles, eds, ASTM, West Conshohocken (1990) p. $225-239$

[5] R.E. Gibson and K.Y. Lo: A theory of soil exhibiting secondary compression Acta Polytech Scand, C (10) (1961)

[6] M. El-Fadel, S. Shazbak, E. Saliby and J. Leckie: Comparative assessment of settlement models for municipal solid waste landfill applications, Waste Management Resources 17 (5) (1999) p. $347-368$

[7] ASTM (American Society of testing and Materials), Annual Book of Standards, West Conshohocken, PA (2006)

[8] M.P. Nur Irfah, H. Omar and M.Y. Zainuddin: Geotechnical properties of Waste Soil from Open Dumping Area in Malaysia, EJGE, Vol. 16 K (2011) p. 2011-090

[9] C.H. Hettiarachchi, J.N. Meegoda and J.P.A. Hettiaratchi: Settlement of Bioreactor Landfills, Modeling of Settlement Behavior of Bioreactor Landfills; Interim Report, Department of Civil Engineering, University of Calgary, Alberta, Canada (2003)

[10] D.G. Coumoulus and T.P. Koryalos: Prediction of attenuation of landfill settlement rates with time, Proc $14^{\text {th }}$ Int. Conf. on Soil Mechanics and Foundation Engineering, Vol. 3, ISSMFE, Hamburg, Germany (1997) p. 1807-1811. 